\title{
Inter Regional Cooperation Policy Through Determination of Anti Corruption Integrity Zone for Achieving Good Governance Principles
}

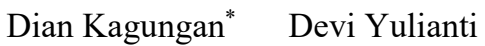 \\ Public Administration Department, Universitas Lampung, 35145, Lampung, Indonesia
}

\begin{abstract}
The research is about the Inter Regional Cooperation Policy Model (Government of Metro City and Pringsewu District, Lampung Province, Indonesia). The method used in this study was descriptive with a qualitative approach. Data was collected through observation, field visits, interviews, documentation and focus group discussions. The results of the research and conclusions obtained were Simplification of service procedures at the One Stop Office of Investment and Integrated Services also the Population and Civil Registry Service of Metro were part of the service system in the context of accelerating service processes. Reorganization was done by sharpening the tasks, principal and function of the agency with the aim that the basic tasks and functions of the work unit. An important suggestion to do was the commitment of Metro City as an anti corruption integrity zone followed and emulated by other regencies/cities in Lampung Province in particular and in the future so the local Government was able to improve services to the community.
\end{abstract}

Keywords: cooperation between regions; anti corruption integrity zone; good governance

DOI: $10.7176 / \mathrm{JLPG} / 86-06$

Publication date: June $30^{\text {th }} 2019$

\section{Introduction}

As a long established city of education, public services in Metro, Lampung Province has not reflected the principles of good governance. This fact was strengthened based on the release of the Corruption Eradication Commission (KPK) on June 10, 2013, the results of the National Integrity Index (IIN) survey placed Metro in the lowest rank of 60 cities in Indonesia. The survey of public sector integrity by the Corruption Eradication Commission (KPK) was carried out at Metro government agencies, including service units for making KTP, SIUP, and IMB. The poor quality of public services in Metro was seen in terms of human resources (HR) where there were several weaknesses, including unprofessionalism, lack of competence empathy and ignoring ethics in service. Public sector orientation plays an important role in the public performance. There are some indicators of governemnt orientations : judical efficiency, bureaucratic efficiency, and the lack of corruption (Shah, 1997). Another prespective that is essential to create excellent public service is social accountability as a means in achieving good governance and increasing pubic participations for improving public service delivery, (Ahmad, 2008).

The launching of the Integrity Zone towards the Corruption Free Region on the 4th June 2012 in Metro as a statement of attitude and joint commitment to fight all forms of corruption, as well as in the framework of bureaucratic reform and improving the quality of public services through the signing of integrity pacts by all officials and apparatus. Corruption is the missuse of power and authority (Salifu et al, 2018). From Mahmood reserach (2010) stated that the quality of public administration must be improved and accountable as an integrated part of good governance.

The commitment of Metro Government in improving the integrity of the apparatus, especially the public service sector was acknowledged by the Corruption Eradication Commission. Corruption according to Hansen and Stanusch (2013) had become the dominant perception that destroyed the legitimacy of political institutions including discredit private business, missalocates human skills, social and aconomic inequalities, and the rule of law.

The seriousness of Metro outlines the problem of the quality of public services has succeeded in placing it as 4 regions with an increase in significant integrity scores ( $>2$ points). The public service integrity index in Metro places it above the City of Bandarlampung and other districts/cities. Meanwhile, the results of the team's research and the study in Pringsewu District Public Care Concern Forum (2012) as a new autonomous region (DOB) in 5 years ago, Pringsewu had the same function for its people. The new regional government in this context also had the obligation to carry out public service activities in a prime manner and to apply the principles of good governance to the people who were in the scope of their territory. But in reality, good and quality public services that reflect the principles of good governance had not been achieved in Pringsewu, even the Regional Government seemed to ignore public services. In infrastructure development, the Regional Government prioritizes office construction rather than public service places. The sustainability of regional development is significant for explored with different lenses such as 1). Participations build trusts, 2). Polycentric and 
multilayered institution improvements, 3). Accountable authorities, (Lebel et al, 2006). From the case above, cooperative relationship between the practice of government in the provinces is able to influence both national and provincial legislation to local government, (Shah, 2006).

The key to the problems above were based on normative aspects in the implementation of public services and the condition of the existing public service locations in two regions (Metro and Pringsewu, Lampung Province Indonesia), a Cooperation Policy Model in the field of Public Services needs to be achieved through Capacity Strengthening Local Institution and Human Resources "Grand design and Road map for Bureaucratic Reform" by the Central Government, among others, through the provision of quality public services along with the application of good governance principles as it is important to improve the quality of governance. It is urgent for economic development, (Mauro, 2004). Since the governance had become the hot theme and plays the determinant society well being The principles of good governance is controversial and difficult. Those five base principles are : 1). Legitimacy and Voice, 2). Direction, 3). Performance, 4). Accountability, and 5). Fairness.

\section{Objectives and Benefits of Research}

The specific objective achieved in this study was Producing an Inter Regional Cooperation Policy Model (Government of Metro City and Pringsewu District which were the location of this research) through the establishment of the Integrity Zone towards the Corruption Free area. The specific benefits of this research were: Performing bureaucratic reform in the regions along with the establishment of a grand design and road map for bureaucratic reform by the Central Government, among others through the provision of quality public services along with the application of good governance. Producing legal draft cooperation policy models and public service models with new autonomous regional governments through strengthening local institutional capacity and human resources as well as identifying aspects that contributed to the development of bureaucratic reform models and alternative models of public services in new autonomous regions. Improving the bureaucratic internal and external supervision system so that bureaucratic reform run better by increasing the participation of the community to continue to oversee the implementation of bureaucratic reform not only in the field of public services but in all fields so that "collusion" practices become public discussion in the country lately and other manipulation practices were minimized or even eliminated.

\section{Methods}

This study consisted of field research and activities in the laboratory. Field research was conducted in Metro and District. Whereas laboratory activities were carried out in the Public Policy Laboratory of the Public Administration Department, Faculty of Social and Political Sciences and Laboratory of Governmental Science Department, and Lab of the State Law Administration, Faculty of Law, Universitas Lampung. Collaboration between laboratories in the Universitas Lampung is usually carried out in every research activity, community service and other Tri Dharma activities of Higher Education. This type of research was descriptive with a qualitative approach. Through a descriptive qualitative approach, the researcher intended to make an objective representation of the symptoms contained in the research problem, namely the model of the cooperation policy of the new autonomous regional government through strengthening institutional capacity and human resources (HR) in the framework of providing public services with good governance insight. Primary data was obtained through key informants who are competent with this research study, namely:

a. Key Informants/resource persons selected purposively based on their competence in the aspects of thinking and managing public services. The informants came from the Metro Government and Pringsewu Government (Executive/Agency, Service, Bureau, Technical Implementation Unit (UPT) to District and Legislative levels), Metro and Pringsewu Inspectorate, Population and Civil Registry Service, Service Institution, the Ombudsman Institution, as well as Informants with a Bureaucrat background/Public service Apparatus are also selected from public service agencies in the Metro and Pringsewu Governments that were identified based on their main tasks and functions in the Regional Government Agencies.

b. The recipient community of services chosen purposively.

c. Stakeholders who were concerned about bureaucratic reform in order to provide excellent public services include those from non governmental organizations and academics.

As secondary data, documents, regulations and archives that were related to the substance of the study will be used in the initial stage, data analysis was performed using statistical techniques, then the analysis was carried out qualitatively. According to Lawrence Neuman (2014) that activities in data analysis were carried out interactively and taken place continuously until complete so that the data was saturated. In qualitative research, the stages of data analysis include data reduction, data presentation and verification/conclusion drawing. To determine the validity of the data in qualitative research must meet several requirements in the examination of data using 4 (four) criteria (Creswell, 2009), namely: credibility, transferability, dependability, confirmability. To examine credibility the researcher triangulated, and negative case analysis techniques by collecting examples 
and cases that were not in accordance with the patterns and trends of information that had been collected and used as comparative material.

\section{Results and Discussion}

Public services are chosen as the main movers because efforts to realize values that have characterized the practice of good governance in public services are done more real and easily. Values such as efficiency, transparency, accountability and participation are translated relatively easily in the implementation of public services. Developing a public service system that has good governace insight are done relatively more easily than institutionalizing these values in all aspects of government activities.

The selection of public service reforms as the main driver is also considered strategic because public services are considered important by all actors from all elements of governance. There are at least 3 (three) reasons that the renewal of public services encourage the development of good governance practices in the country. First, improving the performance of public services is considered important by all stakeholders, namely the government, community members and market participants. The government has an interest in improving public services because if they succeed in improving public services, they will be able to improve legitimacy. Improving public services will also reduce the cost of bureaucracy, which in turn improve the welfare of the citizens and the efficiency of the market mechanism.

Reforming public services will gain broad support. Secondly, public services are the domain of the three elements of governance that have very intensive interactions. Through the implementation of public services, the government improve the quality of services whose benefits are directly felt by the community. Third, the values that have characterized good governance practices are translated relatively easily and significantly through public services. Values such as efficiency, fairness, transparency, participation, and accountability are measured easily in the practice of organizing public services. The success of implementing these values in public services is transmitted to other domains. In this way, good governance is gradually institutionalized in every aspect of government activities. (Agus Dwiyanto, 2005: 6).

The Integrity Zone towards a Corruption-Free Area accompanied by the Implementation of Good Governance in the field of public services. Determination of integrity zones and corruption free zones begins with the launching of the integrity zone first, namely the signing of an anti-corruption agreement based on letter Number 498/III.15/HK/2012 concerning the Establishment of Regional Work Units (SKPD) within the Metro Government as an integrity zone towards corruption free region accompanied by the signing of an integrity pact by all employees and published to the public. The next form of activity is to hold socialization, to all Regional Work Units (SKPD) by Metro City Inspectorate, and guidance related to the signing of the integrity pact, whether all apparatus have signed the integrity pact, and whether it has been implemented in the implementation of public service activities.

Metro City Inspectorate as the driving force and internal appraiser of the Regional Work Unit (SKPD) was declared as an integrity zone towards a corruption free region. Assessment was carried out based on established indicators to measure the level of implementation of activities and effectiveness of activities in the context of preventing corruption. Determination of integrity zones towards corruption free areas was expected to provide opportunities for improving integrity and reducing the number of corruption that occurs in the bureaucratic environment.

The quality of public services in the area was influenced by many factors. The performance of service providers as a spearhead was a downstream problem of complex bureaucratic problems. Community expectations and attitudes towards public services also become factors that influence service integrity.

1. Public Services at the Metro Population and Civil Registry Service

Implementation of Metro Government Bureaucracy Reform Policy through the Establishment of an Integrity Zone towards a Corruption Free Area along with the Implementation of Good Governance in the field of public services In Metro City Population and Civil Registration Office in the form of pruning procedures related to simplification of procedures for Population Cards, Family Cards and birth certificate management, where previously the birth certificate for a child above one year must go through a trial process, but at this time it was no longer so that the process of making a birth certificate became faster.

The non criticism and the spirit of change shown by the Mayor of Metro and his ranks brought changes to the city in a better direction. After obtaining a public service integrity score of 2.16 in 2011, the improvements made by Metro Government in improving the quality of public services. The National Integrity Index value for public services in 2012 totaled 5.31. Based on the results of the survey, Metro was in the fourth rank of the National whose integrity index score had increased significantly from 3.51 to 5.31. This value was still higher than Bandarlampung as the capital city of Lampung Province which was only worth 5.19.

The Corruption Eradication Commission's version of the Public Service Integrity Score was as follows:

a. Metro in 2011 (3.15), the lowest of the 60 regional/district/city governments surveyed, in 2012 the public service integrity score increased to 5.31 . 
b. Bandar;ampung in 2012, the public service integrity score reached 5.19.

c. Areas such as Lubuk Linggau public service integrity score 4.38 to 6.80 .

d. Manokwati public service integrity score from 3.70 to 6.00 .

e. Serang City public service integrity score from 3.54 to 6.57 , Semarang City public service integrity score from 3.61 to 5.66 and Tangerang city public service integrity score from 4.46 to 6.57

Although Metro integrity index value in 2012 had increased, the value was still not optimal. The integrity index value that should be achieved by the Metro Government was the value of 6.00 as the National integrity index value standard or even more than 6.00. Achievement of the value of the National integrity index that had not been maximized indicated by the obstacles faced by Metro Government in reforming the public services provided. One of the improvements in public services in Metro was at the Office of Investment and One-Stop Services (KPM PTSP). The SIUP management services for a maximum of three days and even only two days, there was a standard service procedure (SOP) which contains the provision that the licensing service was a maximum of seven days, and even then there were several types of licensing that require adequate space. Regarding transparency, the One-Stop Integrated Investment and Services Office (KPM PTSP) had collaborated with the Bank, with this collaboration the One-Stop Integrated Services and Investment Office (KPM PTSP) employees did not come into direct contact with the money for licensing fees, because the payment directly at the Bank window. To improve service facilities, at the One Stop Integrated Investment and Services Office (KPM PTSP) there were six counters including bank counters and complaint information counters. There were at least 14 licensing items free of charge, one of which was SIUP, IMB management and disruption permits.

Metro City Population and Civil Registry Service had also made various improvements, specifically for the management of residents' identity cards (KTP), they could wait if the files had been entered into the Population and Civil Registry Service for a maximum of 3 days. In addition, the Population and Civil Registration Office had also informed the public about the rates for making ID cards in accordance with Metro regulations as a form of transparency and provided suggestions and complaints from the public as a form of transparency and installation of CCTV cameras as surveillance cameras at public service counters with the hope of the people did not to use the services of brokers.

The prevalence in this government environment had indeed created a dilemma among Civil Servants including the National Police, Prosecutors, Judges, TNI and others. As a result, there were still few state administrators or civil servants who utilize gratification reporting facilities. In addition there were psychological obstacles for civil servants to report the game of gratification to the Corruption Eradication Commission (KPK). This was necessary for the Gratuity Control Program or the Corruption Prevention Program, because the gratification was corruption. It needed the active role of agencies in improving compliance with gratuity control by building a conducive environment and a good control system. The aim of the Gratification Control Program was to establish an environment in an institution or organization that was conscious and controlled in handling gratification practices so the principles of transparency and accountability were increasingly implemented. This moral message had been noted in history, how our previous leaders flatly rejected giving in his office and not his personal rights. Even some of them later resigned from their positions because they were known to receive gifts or bribes. "Efforts to assess the Metro City Government's strategy in creating high integrity cities through administrative reform strategies (Caiden, 1991) were measured through indicators, including the following: (a) debureaucratization, (b) reorganization (c) public management effective (d) value for money.

2. The policy of cooperation between regions in the framework of providing good public service that is insightful

In the context of cooperation between regions the important thing that cannot be ignored is the need for clear and definite legal or regulatory about the source of the budget to finance the initiation of cooperation between regions. Building on the commitment of regional leaders to the importance of cooperation between regions, in other words regional leaders must work together and build mutual agreements in building good relations between regions for the progress of their respective regions. Next, as quoted from Dr. Ir. Antonius Tarigan Msi, Spatial Planning Bulletin, March-April 2009 edition: Increasing Regional Competitiveness (kota.blogspot.com planning access on June 6, 2015 "Indonesian Urban Planning, Theory, Concepts and Urban Planning and Problems with Cities in Indonesia") that cooperation between regions so far was inseparable from the obstacles that occur in its implementation. These constraints are as follows: (1) the absence of a sufficiently good database on interregional cooperation in Indonesia (2) Local Governments are still not sufficient to consider cooperation between regions as one of the innovations in the implementation of development. One reason is the regional ego where the spirit of regional autonomy is still seen as narrow and regional. This condition impacts regional initiatives to cooperate with other regions, especially because it is not uncommon for public services to be managed through inter regional cooperation to lose more and be subsidized by regional budgets so cooperation is less attractive (3) for newly created regions, there is a tendency to be more reluctant to cooperate with other regions, because new euphoria becomes an autonomous region. 
Collaboration between the Government of Metro and Pringsewu in the framework of providing public services to the community based on the principles of good governance (transparent, fast, precise, simple, safe, affordable and certainty) was very much in accordance with the implementation agenda of Bureaucratic Reform in 2010-2014. Public services provided by the government bureaucracy demand high moral responsibility. But unfortunately this moral responsibility and professional responsibility were one of the crucial weak points in the public service bureaucracy in Indonesia, coupled with the weak internal and external supervision system in overseeing the implementation of public service bureaucratic reform. Therefore it is necessary to change the paradigm and culture of public service among the bureaucratic apparatus. The bureaucracy is the servant of society and not the opposite of the ruler of society. This change in cultural paradigm and mentality is done through the creation of policies that encourage the creation of public services oriented to the fulfillment and protection of civil rights of citizens, as well as law enforcement against existing laws and regulations. The creation of public service policies is directed at providing legal certainty, procedures, deadlines, community participation and strengthening community rights to sue bodies or officials who carry out administrative malls or abuse of power. While efforts to strengthen law enforcement are carried out by creating law enforcement officers who are clean, authoritative and fair.

According to the research team's study, cases of corruption, collusion/nepotism, was one proof of the failure of bureaucratic reforms as well as weak supervision, regulation and systems, because it was necessary to create a model of policy formulation that was not only limited to the service sector but also included all fields. The acceleration of bureaucratic reform was intended so the local governments provided quality public services along with the application of good governance, in addition to appreciating regions that were ready to be assessed by the Government in providing public services with good government and clean governance while stimulating regions others in Indonesia to immediately carry out bureaucratic reforms.

\section{Conclusion}

The commitment of the Metro Government in improving the integrity of the apparatus, especially the public service sector, was acknowledged by the Corruption Eradication Commission. The public service integrity index in Metro City placed it above Bandarlampung and other districts/cities. The process of public service in Metro One Stop Office of Integrated Investment and Services, the process of accelerating services was supported by service improvements, including the establishment of service counters, transparency service fees and times, levy payments according to tariffs, installation of CCTV cameras at public service points. Furthermore, trimming public service procedures at the Metro City Population and Civil Registry Service, in the form of simplifying procedures for service cards for residents, family cards, birth certificates, and other civil registration. Reorganization was also carried out by sharpening the duties, principles and functions of the relevant agencies. Furthermore, the Decree of the Mayor of Metro Number 441/KPTS/ 06/2011 dated December 27, 2011 by establishing a Public Service Improvement Task Force in Metro. This task force guides all public service providers to work with high integrity commitments.

\section{References}

A. Farazmand (ed). 2018. Corruption And International Aid. Global Encyclopedia of Public Administration, Public Policy and Governance. Springer International Publication.

Ahmad, R. 2008. Governance, Social Accountabilty and The Civil Society. JOAAG. 3 (1).

Anti Corruption Agreement Number 498/III.15/HK/2012 Concerning The Establishment of Regional Wor Unit Within The Metro Government.

Caiden, Gerald E. 1991. Administrative Reform Comes of Age. Walter de Gruyer. Berlin.

Creswell, John. W. 2009. Research Design : Qualitative, Quantitative, and Mixed Methods Approaches. Sage. Los Angeles.

Dwiyanto, Agus, 2001. Reformasi Birokrasi Publik di Indonesia, Pusat Studi Kependudukan dan Kebijakan (PSKK), Universitas Gajah Mada, Yogyakarta.

Graham, John. Bruce Amos and Tim Plumtre. 2003. Principles For Good Governance In The 21st Century. Institute of Governance. Canada.

Hansen, Hans Krause, Agata Stachowicz Stanusch. 2013. Varieties of Corruption Control : Introduction To Special Issue. Crime Law Soc Change. 60 : 115-126.

Lebel, Louis et al. 2006. Governance and The Capacity To Manage Resilence In Regional Social Ecological Systems. Ecology and Society 11 (1).

Mahmood, Shakeel Ahmed Ibnu. 2010. Public Procurement and Corruption In Bangladesh : Confronting The Challenges and Opportunities. J. Public Adm. Pol Res.

Nauro, Paulo. 2004. The Presistence of Corruption and Slow Economic Growth. IMF Staff Papers 51 (1).

Neuman, W. Lwrence. 2014. Social Research Methods : Qualitative and Quantitative Approaches. Pearson. New York. 
Shah, Anwar. 1997. Balance, Accountability and Responsiveness : Lessons About Decentralization. World Bank. Washington DC.

2006. Public Sector, Governance and Accountability Series : Local Governance in Developing Countries. World Bank. Washington DC. 